Research Article

\title{
The In Vitro Adsorption Ability of Lactobacillus acidophilus NCFM to Benzo(a)pyrene in $\mathbf{P M}_{2.5}$
}

\author{
Lili Fu $\mathbb{D}^{1},{ }^{1}$ Yan Ning $\mathbb{D},{ }^{1}$ Hongfei Zhao $\mathbb{D}^{1,2}$ Junfeng Fan $\mathbb{D}^{1,2}$ and Bolin Zhang $\mathbb{D}^{1,2}$ \\ ${ }^{1}$ College of Biological Science \& Biotechnology, Beijing Forestry University, Beijing 100083, China \\ ${ }^{2}$ Beijing Key Laboratory of Forest Food Processing and Safety, Beijing 100083, China \\ Correspondence should be addressed to Bolin Zhang; zhangbolin888@163.com
}

Received 14 January 2020; Revised 22 June 2020; Accepted 3 July 2020; Published 7 January 2021

Academic Editor: Orish Ebere Orisakwe

Copyright ( 92021 Lili Fu et al. This is an open access article distributed under the Creative Commons Attribution License, which permits unrestricted use, distribution, and reproduction in any medium, provided the original work is properly cited.

\begin{abstract}
The objective of this work was to explore the ability of lactic acid bacteria strains to bind benzo(a)pyrene (B(a)P) existing in $\mathrm{PM}_{2.5}$. In this study, we examined the ability of Lactobacillus acidophilus NCFM to bind $\mathrm{B}(\mathrm{a}) \mathrm{P}$ in the simulated $\mathrm{PM}_{2.5}$ environment. Among the tested 5 strains, Lactobacillus acidophilus NCFM exhibited the best capacity to bind $\mathrm{B}(\mathrm{a}) \mathrm{P}$, and its $\mathrm{B}(\mathrm{a}) \mathrm{P}$ binding percentage was $60.00 \%$. Simulations of organic and inorganic systems which represent $\mathrm{PM}_{2.5}$ indicated that $\mathrm{B}(\mathrm{a}) \mathrm{P}$ could be absorbed by strain L. acidophilus NCFM. For the inorganic system of $\mathrm{pH} 5$, L. acidophilus NCFM bound 92.74\% B(a)P with a cell concentration of $1 \times 10^{10} \mathrm{cfu} / \mathrm{mL}$ at $37^{\circ} \mathrm{C}$ for $8 \mathrm{hr}$. Regarding the organic system with $\mathrm{pH} 6,73.00 \% \mathrm{~B}(\mathrm{a}) \mathrm{P}$ was bound by strain L. acidophilus NCFM after this bacterium was incubated at $37^{\circ} \mathrm{C}$ for $10 \mathrm{~min}$. A quick B(a)P binding by this probiotic bacterium took place in the organic system. The removal of $\mathrm{B}(\mathrm{a}) \mathrm{P}$ from $\mathrm{PM}_{2.5}$ was significantly related to incubation time, cultivation temperature, $\mathrm{pH}$, and cell concentration. Thus, our finding shows that long-term consumption of L. acidophilus NCFM is beneficial for the reduction of $\mathrm{B}(\mathrm{a}) \mathrm{P}$ towards the population who are exposed to $\mathrm{PM}_{2.5}$, although the ability of this bacterium to adsorb $\mathrm{B}(\mathrm{a}) \mathrm{P}$ is partly affected by the differences in the origin of $\mathrm{PM}_{2.5}$.
\end{abstract}

\section{Introduction}

Particulate matter, harmful suspended particles existing in air environment, is referred as small particles less than 10 micrometers. The particulate matter is easily deposited in the upper respiratory tract and causes toxicity to the human body. Such particulate matters which are less than $2.5 \mathrm{mi}-$ crometers in diameter, i.e., $\mathrm{PM}_{2.5}$, are more dangerous and have a direct damage to lung health due to long-term contact of bronchioles and alveoli [1]. The smaller the particle diameter is, the deeper into the respiratory tract happens. Meanwhile, toxicological data show that particulate matters not only affect the respiratory ability but also are harmful to cardiovascular, nervous, and immune functions [2]. Thus, the World Health Organization (WHO) defines particulate matter as a class of carcinogens and addresses that different degrees of physiological and pathological changes will take place for the particulate matter-carrying population [3].

Generally, $\mathrm{PM}_{2.5}$ consists of sulfate, nitrate, ammonium salts, carbonaceous particles, metal particles, minerals, and polycyclic aromatic hydrocarbon (PAH) family [4, 5]. Benzo(a)pyrene (B(a)P), a member of the family $\mathrm{PAH}$, is usually found in its $\mathrm{PM}_{2.5}$. The presence of $\mathrm{B}(\mathrm{a}) \mathrm{P}$ in $\mathrm{PM}_{2.5}$ significantly strongly increases tumor cell migration and invasion, causing mutagenesis and carcinogenicity [6]. B(a)P from the PAH family is regarded as the most abundant and toxic component existing in $\mathrm{PM}_{2.5}$ and has long-term harm to people. Thus, it is practicable to use $\mathrm{B}(\mathrm{a}) \mathrm{P}$ as a marker to elevate the toxicity of $\mathrm{PM}_{2.5}$ [7].

In recent years, there has been an increasing interest in $\mathrm{PM}_{2.5}$ which is a significant threat to human health [8]. In addition to activated carbon and modified mesoporous organosilica which are traditionally used as adsorbing agents of $\mathrm{PM}_{2.5}$, microbial community is also becoming an important part of filtration media, and lactic acid bacteria strains could be explored as a bio-binding material for the removal of $\mathrm{PM}_{2.5}$ [9]. Lactobacillus strains, as food-grade microorganisms from lactic acid bacteria, have good intestinal adhesion ability of epidermal cells and thus offer various health-promoting benefits to the human body [10]. 
The communication between Lactobacillus strains defined as probiotics and intestinal cells can stop the colonization of pathogens from the intestine and enhance the immunity of the body [11]. Lactobacillus strains have been documented to have good adsorption to mutagenic compounds, thus being a biological agent for anticancer or antimutagenic effect [12]. Some Lactobacillus strains are also proved to significantly reduce the mutagenicity of $\mathrm{B}(\mathrm{a}) \mathrm{P}$ via their binding ability $[13,14]$. In our cases, L. plantarum CICC 22135 and L. pentosus CICC 23163 exhibited high efficiency in removing $\mathrm{B}(\mathrm{a}) \mathrm{P}$ from the aqueous medium [15]. Moreover, such Lactobacillus strains showed a good B(a)P binding ability under simulated starch conditions, but their $\mathrm{B}(\mathrm{a}) \mathrm{P}$ binding percentages depended on starch concentrations [16]. Studies have shown the importance of bacteria in binding PAHs, and this reduction is significantly affected by initial PAH concentrations, bacterial population, and $\mathrm{pH}$ of media; especially, the highest reduction was related to $\mathrm{B}(\mathrm{a}) \mathrm{P}$ [17]. Obviously, the roles of Lactobacillus strains in B(a)P binding are affected by the environments in which they survive. To date, few relevant studies on whether Lactobacilli strains are still able to bind $\mathrm{B}(\mathrm{a}) \mathrm{P}$ in $\mathrm{PM}_{2.5}$ with complex and diverse particulate matter have been done. Therefore, this present study was designed to investigate the possibility of strain $L$. acidophilus NCFM to remove $\mathrm{PM}_{2.5}$ toxicity in terms of its $\mathrm{B}(\mathrm{a}) \mathrm{P}$ binding ability. Possible factors affecting these tested strains to bind $\mathrm{B}(\mathrm{a}) \mathrm{P}$ were also discussed when they were cultured in the simulated $\mathrm{PM}_{2.5}$ systems. Imaging the cell morphology of L. acidophilus NCFM in the simulated $\mathrm{PM}_{2.5}$ systems via atomic force microscopy (AFM) was presented.

\section{Materials and Methods}

2.1. Bacterial Strains. Several LAB strains including Lactobacillus plantarum 121, Leuconostoc mesenteroides DM1-2, Lactobacillus acidophilus NCFM, Lactobacillus paralimentarius 412, and Lactobacillus pentosus ML32 were obtained from the China Center of Industrial Culture Collection (CICC) and tested for this study.

2.2. Preparation of Bacterial Suspensions. The lyophilized preparations of five strains transferred into $5 \mathrm{~mL}$ de Man-Rogosa-Sharpe (MRS) medium were firstly activated at $37^{\circ} \mathrm{C}$, respectively. Then, they were inoculated into the MRS medium at $37^{\circ} \mathrm{C}$ for $12 \mathrm{hr}$ incubation with $4 \%$ inocula. Their cells were collected by centrifugation $\left(4^{\circ} \mathrm{C}, 5000 \mathrm{rpm}\right.$, and $10 \mathrm{~min}$ ) and washed twice with sterile water. The cell concentrations of these tested strains were finally adjusted to $5 \times 10^{9} \mathrm{cfu} / \mathrm{mL}$ prior to use.

\subsection{Preparation of Two B(a)P Simulation Systems}

2.3.1. Inorganic System. The $\mathrm{PM}_{2.5}$-based inorganic compositions simplify the artificial inorganic system. Artificial inorganic system $(1.0 \mathrm{~mL})$ consisting of $100 \mu \mathrm{L}$ of $\mathrm{B}(\mathrm{a}) \mathrm{P}$ working solution $(10 \mu \mathrm{g} / \mathrm{mL}), 300 \mu \mathrm{L}$ of sodium sulfate solution $(100 \mu \mathrm{g} / \mathrm{mL}), 300 \mu \mathrm{L}$ of ammonium sulfate solution
$(100 \mu \mathrm{g} / \mathrm{mL})$, and $100 \mu \mathrm{L}$ of sterile water was designed according to Dhananjay et al. with some modifications [5].

2.3.2. Organic System. Regarding the organic compositions of $\mathrm{PM}_{2.5}$ which belong to the family PHAs, PHA Mix (EPA 610), purchased from Accredited Chemical Testing Lab with a purity $\geq 98.5 \%$, was used to simulate the organic system of $\mathrm{B}(\mathrm{a}) \mathrm{P}$. The PHA Mix consists of 16 various concentrations of organic compounds, including benzo[k]fluoranthene of $99.37 \pm 1.4 \mathrm{mg} / \mathrm{L}$, chrysene of $99.59 \pm 1.41 \mathrm{mg} / \mathrm{L}$, phenanthrene of $98.9 \pm 1.31 \mathrm{mg} / \mathrm{L}$, benzo[b]fluoranthene of $202.3 \pm 2.69 \mathrm{mg} / \mathrm{L}$, benzo[ghi]perylene of $200.6 \pm 2.67 \mathrm{mg} / \mathrm{L}$, fluoranthene of $198.3 \pm 2.64 \mathrm{mg} / \mathrm{L}$, fluorine of $200.4 \pm 2.66 \mathrm{mg} / \mathrm{L}$, naphthalene of $1000 \pm 3.74 \mathrm{mg} / \mathrm{L}$, acenaphthene of $991 \pm 6.1 \mathrm{mg} / \mathrm{L}$, acenaphthylene of $2018 \pm 12.31 \mathrm{mg} / \mathrm{L}$, anthracene of $101.2 \pm 1.34 \mathrm{mg} / \mathrm{L}$, benzo [a] anthracene of $99.98 \pm 1.41 \mathrm{mg} / \mathrm{L}$, benzo[a]pyrene of $100.8 \pm 1.34 \mathrm{mg} / \mathrm{L}$, dibenz[a,h]anthracene of $202 \pm 2.86 \mathrm{mg} /$ $\mathrm{L}$, indeno[1,2,3-cd]pyrene of $98.61 \pm 1.39 \mathrm{mg} / \mathrm{L}$, and pyrene of $100.6 \pm 1.33 \mathrm{mg} / \mathrm{L}$. The simulated organic system of $\mathrm{B}(\mathrm{a}) \mathrm{P}$ was composed of $100 \mu \mathrm{L}$ PHAs $(100 \mu \mathrm{g} / \mathrm{mL})$ and $900 \mu \mathrm{L}$ sterile water.

The separation of sixteen kinds of PAHs within $35 \mathrm{~min}$ showed good linearity in the range of $0.10-5.00 \mu \mathrm{g} / \mathrm{mL}$, and the detection limit of $\mathrm{B}(\mathrm{a}) \mathrm{P}$ was $0.90 \mu \mathrm{g} / \mathrm{mL}[18,19]$.

\subsection{Binding of Tested Strains to B(a)P in Two Simulated Systems}

2.4.1. Inorganic System. The artificial inorganic system $(100 \mu \mathrm{L})$ plus $900 \mu \mathrm{L}$ sterilized water, containing $1.0 \mu \mathrm{g} / \mathrm{mL}$ $\mathrm{B}(\mathrm{a}) \mathrm{P}$, was added to $1.0 \mathrm{~mL}$ bacterial suspension. After incubation at $37^{\circ} \mathrm{C}$ for $4 \mathrm{hr}$, the supernatant was collected by centrifugation $(3000 \mathrm{r} / \mathrm{min}, 5 \mathrm{~min})$. Chloroform $(500 \mu \mathrm{L})$ was added to the supernatant to produce the organic phase for the detection of $\mathrm{B}(\mathrm{a}) \mathrm{P}$. The control was designed as $1.0 \mu \mathrm{g} / \mathrm{mL}$ aqueous solution of $\mathrm{B}(\mathrm{a}) \mathrm{P}$ without bacterial cell addition. For each sample, B(a)P was detected by HPLC with the following conditions: UV detection of $290 \mathrm{~nm}$ wavelength, mobile phase of pure methanol, selection of room temperature as column temperature, flow rate of $1.0 \mathrm{~mL} /$ min, and injection volume of $20.0 \mu \mathrm{L}$ [18].

2.4.2. Organic System. We selected $100 \mu \mathrm{L}$ PHAs plus $900 \mu \mathrm{L}$ sterilized water which were added to $1.0 \mathrm{~mL}$ bacterial suspension. After incubation at $37^{\circ} \mathrm{C}$ for $4 \mathrm{hr}$, the level of $\mathrm{B}(\mathrm{a}) \mathrm{P}$ existing in the supernatant collected by centrifugation ( $3000 \mathrm{r} / \mathrm{min}, 5 \mathrm{~min}$ ) was detected by HPLC. The control was $1.0 \mu \mathrm{g} / \mathrm{mL}$ PHAs $(1.0 \mathrm{~mL})$ without bacterial cell addition. $\mathrm{B}$ (a)P was UV-detected at $290 \mathrm{~nm}$ wavelength by HPLC. Acetonitrile and water were used as the mobile phase. Column temperature was room temperature with a flow rate of $1.0 \mathrm{~mL} / \mathrm{min}$ as well as injection volume of $20.0 \mu \mathrm{L}$. For gradient elution analysis, $\mathrm{A}$ was acetonitrile and $\mathrm{B}$ was water. $60 \%$ A plus $40 \%$ B was used for isocratic elution for $1 \mathrm{~min}$. After A was elevated from $60 \%$ to $100 \%$ within $20 \mathrm{~min}$, eluting with $100 \%$ A was kept for at least $22 \mathrm{~min}$. Then, 
elution A was reduced to $60 \%$ in $8 \mathrm{~min}$ and equilibrated with $60 \% \mathrm{~A}$ for $10 \mathrm{~min}$.

2.4.3. The Binding Percentage of Strains to $B(a) P$. The binding percentage of the tested bacteria to $\mathrm{B}(\mathrm{a}) \mathrm{P}$ was calculated according to the following equation:

$$
B_{r}=\frac{\left(B_{s}-S\right)}{B_{s}} \times 100 \%,
$$

where $B_{r}$ represents the binding rate of the tested bacterial cells to $\mathrm{B}(\mathrm{a}) \mathrm{P}(\%) ; B_{s}$ indicates the level of $\mathrm{B}(\mathrm{a}) \mathrm{P}$ from the sample blank $(\mu \mathrm{g} / \mathrm{mL})$; and $S$ is the level of $\mathrm{B}(\mathrm{a}) \mathrm{P}$ for each supernatant harvested from the tested bacterial cultivation $(\mu \mathrm{g} / \mathrm{mL})$.

\subsection{Factors Affecting the Ability of L. acidophilus NCFM to Bind $B(a) P$}

2.5.1. Effect of Incubation Time. For either of the simulated inorganic or organic system, L. acidophilus NCFM was grown in both systems for the observation of its $\mathrm{B}(\mathrm{a}) \mathrm{P}$ binding ability under different incubation times at $37^{\circ} \mathrm{C}$. After incubated in two simulated systems for $10 \mathrm{~min}, 60 \mathrm{~min}$, $240 \mathrm{~min}, 480 \mathrm{~min}, 1080 \mathrm{~min}$, and $1440 \mathrm{~min}$, respectively, the percentage of strain NCFM to bind B(a)P was detected.

2.5.2. Effect of Temperature. For either of the simulated inorganic or organic system, L. acidophilus NCFM was cultivated in the two simulated systems for the observation of its $\mathrm{B}(\mathrm{a}) \mathrm{P}$ binding ability under different incubation temperatures. The ability of $L$. acidophilus NCFM to bind $\mathrm{B}(\mathrm{a}) \mathrm{P}$ was evaluated after this strain was incubated at $4^{\circ} \mathrm{C}$, $15^{\circ} \mathrm{C}, 23^{\circ} \mathrm{C}$, and $37^{\circ} \mathrm{C}$ for $8 \mathrm{hr}$, respectively.

2.5.3. Effect of $p H$. For either of the simulated inorganic or organic system, L. acidophilus NCFM was cultured in the two simulated systems for the observation of its $\mathrm{B}(\mathrm{a}) \mathrm{P}$ binding ability under different $\mathrm{pH}$ values at $37^{\circ} \mathrm{C}$. The ability of $L$. acidophilus NCFM to bind B(a)P was evaluated after

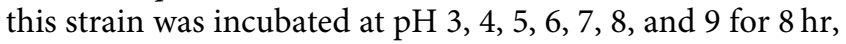
respectively. The sample was adjusted to a specific $\mathrm{pH}$ value using a degassed phosphate buffer solution.

2.5.4. Effect of Cell Concentration. For either of the simulated inorganic or organic system, L. acidophilus NCFM was grown in the two simulated systems for the observation of its $\mathrm{B}(\mathrm{a}) \mathrm{P}$ binding ability under cell concentrations. L. acidophilus NCFM was inoculated into the two simulated systems at cell concentrations of $1 \times 10^{8} \mathrm{cfu} / \mathrm{mL}, 1 \times 10^{9} \mathrm{cfu} /$ $\mathrm{mL}$, and $1 \times 10^{10} \mathrm{cfu} / \mathrm{mL}$, respectively. Estimation of cell concentrations during cultures was done by turbidimetry [20]. After incubated at $37^{\circ} \mathrm{C}$ for $8 \mathrm{hr}$, the ability of this strain to bind $\mathrm{B}(\mathrm{a}) \mathrm{P}$ was evaluated in terms of its cell concentrations.
2.6. The Optimal Parameters for L. acidophilus NCFM to Bind $B(a) P$. According to Section 2.5, the optimal conditions are obtained from two simulated systems. L. acidophilus NCFM was cultured in the optimal conditions to calculate the best binding percentages of $\mathrm{B}(\mathrm{a}) \mathrm{P}$.

2.7. Analysis of Atomic Force Microscopy (AFM). Atomic force microscopy was used to observe the possibility of L. acidophilus NCFM $\left(10^{9} \mathrm{cfu} / \mathrm{mL}\right)$ to bind B(a)P. Four groups were prepared as follows. The first group was the inorganic system which contains $10 \mu \mathrm{g} / \mathrm{mL} \mathrm{B}(\mathrm{a}) \mathrm{P}$ and strain NCFM; the second was the organic system with $10 \mu \mathrm{g} / \mathrm{mL}$ $\mathrm{B}(\mathrm{a}) \mathrm{P}$ and strain NCFM; the third was $10 \mu \mathrm{g} / \mathrm{mL} \mathrm{B}(\mathrm{a}) \mathrm{P}$ solution plus strain NCFM; and the fourth was only bacterial suspension as the control. These mixtures were incubated at $37^{\circ} \mathrm{C}$ for $1 \mathrm{hr}$ and then diluted to a final concentration of $10 \mu \mathrm{g} / \mathrm{mL}$. $5 \mu \mathrm{L}$ was sampled and dispersed onto a mica carrier (PELCO mica disc $10 \mathrm{~mm}$ ) for drying at room temperature. AFM images were captured by using a scanning probe microscope (NTEGRA Spectra, NT-MDT Co., Ltd., Moscow, Russia) in the tapping mode.

2.8. Statistical Analysis. Three replicates for each experiment were done. Statistical analyses (ANOVA) were performed using SPSS 19.0 statistical software. Results are expressed as means \pm standard deviation (SD). Statistical differences are considered to be significant when $P \leq 0.05$ takes place.

\section{Results}

3.1. The Ability of the Tested Strains to Bind B(a)P. As shown in Figure 1, the five tested bacteria had different abilities to bind B(a)P. L. acidophilus NCFM showed the best capacity for the adsorption of $\mathrm{B}(\mathrm{a}) \mathrm{P}$, followed by strain 121 , strain ML32, strain DM1-2, and strain 412. 60.00\% B(a)P was bound by L. acidophilus NCFM in the present study. It was seen that the ability of lactic acid bacteria to bind $\mathrm{B}(\mathrm{a}) \mathrm{P}$ was strain-dependent. To better understand the roles of various factors in determining the efficiency of $\mathrm{B}(\mathrm{a}) \mathrm{P}$ binding, only L. acidophilus strain NCFM was chosen for further study.

3.2. Factors Affecting the Ability of L. acidophilus NCFM to Bind $B(a) P$. Several factors including incubation time, incubation temperature, $\mathrm{pH}$, and cell concentrations have been reported to directly affect the possibility of potential probiotic bacteria to bind $\mathrm{B}(\mathrm{a}) \mathrm{P}$ if they were presented to different media [21]. To show the possible potential of L. acidophilus NCFM to bind $\mathrm{B}(\mathrm{a}) \mathrm{P}$ in $\mathrm{PM}_{2.5}$, we designed two simulated systems, i.e., inorganic and organic systems, as imaginary $\mathrm{PM}_{2.5}$ to observe the $\mathrm{B}(\mathrm{a}) \mathrm{P}$ adsorbing ability of this strain was subjected to various variables.

3.2.1. Incubation Time. As shown in Figure 2, the highest percentage of strain NCFM to bind $\mathrm{B}(\mathrm{a}) \mathrm{P}$ in the simulated inorganic system was $96.34 \%$ when this bacterium was incubated for $8 \mathrm{hr}$. As the simulated inorganic system was concerned, no clear correlation between the $\mathrm{B}(\mathrm{a}) \mathrm{P}$ binding 


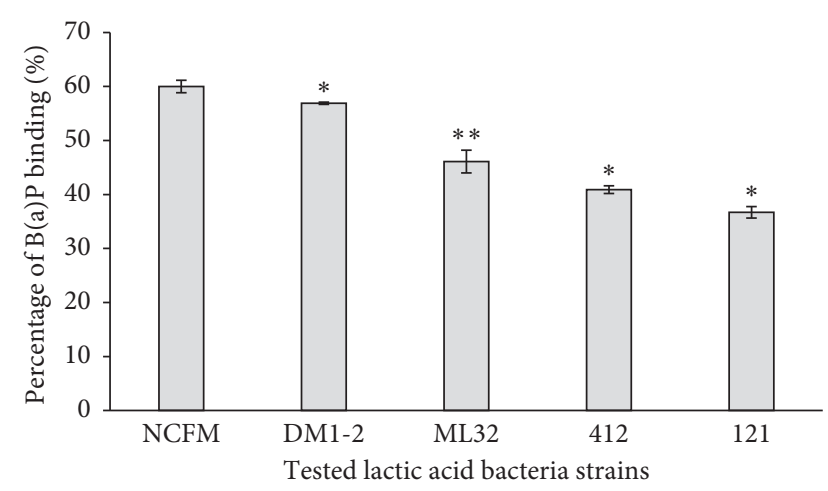

FIGURE 1: B(a)P binding percentage of lactic acid bacteria strains. Note: ${ }^{*} P<0.05$ and ${ }^{*} P<0.01$ compared with strain NCFM.

percentage of strain NCFM and its incubation time was observed (Figure 2(a)). For the organic system, however, the binding of $L$. acidophilus NCFM to B(a)P was a quite quick process. It only took $10 \mathrm{~min}$ for this bacterium to bind most B(a)P. $25.66 \%$ B(a)P was absorbed by this strain after $10 \mathrm{~min}$ incubation. It was seen that the binding percentage of strain NCFM to B(a)P in the inorganic system was higher than that in the organic system at the same incubation time. Thus, the component's complex from $\mathrm{PM}_{2.5}$ might significantly affect the adsorption of strain NCFM to B(a)P.

3.2.2. Temperature. The temperature ranges from $4^{\circ} \mathrm{C}$ to $37^{\circ} \mathrm{C}$ were chosen to investigate the role of incubation temperature in affecting the ability of $L$. acidophilus NCFM to bind $\mathrm{B}(\mathrm{a}) \mathrm{P}$ in $\mathrm{PM}_{2.5}$ (Figure 2(b)). 85.64\% $\mathrm{B}(\mathrm{a}) \mathrm{P}$ was bound by strain NCFM in the simulated inorganic system, but only $29.60 \% \mathrm{~B}(\mathrm{a}) \mathrm{P}$ was bound in the simulated organic system at $37^{\circ} \mathrm{C}$. In both simulated systems, however, it was noted that an elevating incubation temperature was helpful for L. acidophilus NCFM to bind more B(a)P.

3.2.3. $p H$. As the $\mathrm{pH}$ ranges from 3 to 9 were concerned, most $\mathrm{B}(\mathrm{a}) \mathrm{P}$ was bound by L. acidophilus NCFM when $\mathrm{pH}$ of both simulated systems was 5 (Figure 2(c)). Strain NCFM bound $94.11 \% \mathrm{~B}(\mathrm{a}) \mathrm{P}$ for the simulated inorganic system at $\mathrm{pH} 5$ and $54.93 \% \mathrm{~B}(\mathrm{a}) \mathrm{P}$ for the simulated organic system at $\mathrm{pH}$ 6. An acidic to near-neutral medium surrounding seemed to be useful for L. acidophilus NCFM to bind more $\mathrm{B}(\mathrm{a}) \mathrm{P}$ from $\mathrm{PM}_{2.5}$, although this bacterium bound $\mathrm{B}(\mathrm{a}) \mathrm{P}$ more in the simulated inorganic system than in the simulated organic system.

3.2.4. Strain Concentration. It is apparent that the higher the L. acidophilus NCFM cell concentrations are in both simulated systems, the more B(a)P will be bound (Figure 2(d)). About $53.75 \%$ B(a)P was absorbed by strain NCFM when its cell concentration was $1 \times 10^{10} \mathrm{cfu} / \mathrm{mL}$ in the simulated inorganic system, while $41.85 \% \mathrm{~B}(\mathrm{a}) \mathrm{P}$ was bound in the same cell concentration.
3.3. The Optimal Conditions for L. acidophilus NCFM to Bind $B(a) P$. Summary of the aforementioned available data indicated that strain NCFM was able to bind $\mathrm{B}(\mathrm{a}) \mathrm{P}$ either in the inorganic or organic system. When this bacterium was incubated with a cell concentration of $1 \times 10^{10} \mathrm{cfu} / \mathrm{mL}$ at $37^{\circ} \mathrm{C}$ for $8 \mathrm{hr}$ in the inorganic system of $\mathrm{pH} 5$, strain NCFM bound the highest $\mathrm{B}(\mathrm{a}) \mathrm{P}(92.74 \%)$. The optimal parameters for strain NCFM to bind $\mathrm{B}(\mathrm{a}) \mathrm{P}$ were $1 \times 10^{10} \mathrm{cfu} / \mathrm{mL}$ cell concentration and $37^{\circ} \mathrm{C}$ for $10 \mathrm{~min}$ of incubation in the organic system of $\mathrm{pH}$ 6. About $73.00 \% \mathrm{~B}(\mathrm{a}) \mathrm{P}$ was absorbed by this strain under the optimal conditions. It was seen from our present data that at least $60.00 \% \mathrm{~B}$ (a)P could be removed in the presence of L. acidophilus NCFM. Obviously, L. acidophilus NCFM strain might have an ability to remove $\mathrm{B}(\mathrm{a}) \mathrm{P}$ from $\mathrm{PM}_{2.5}$. Thus, consumption of this probiotic bacterium should be beneficial for humans to reduce the damage of $\mathrm{PM}_{2.5}$.

3.4. AFM Analysis. The morphology of the cells was measured by the AFM contact mode, and the single-cell topography of the control group and the three experimental groups was obtained (Figure 3). The morphology of strain NCFM binding B(a)P in the simulated inorganic system or organic system was shrinkage and edge-damaged, whilst the cells of the control group were smooth and intact, showed as normal Lactobacilli cells (Figures 3(a)-3(d)). Moreover, a decrease in the surface roughness of binding cells was also observed for the organic or inorganic system (Figure 3(e)).

\section{Discussion}

Currently, public sectors take regulation actions to reduce emissions and prevent inhalation in order to cope with the $\mathrm{PM}_{2.5}$ problem [22], but there is still no good solution for mitigating the injuries of toxins on the human body. To date, various physical and chemical ways have been tried to reduce the damage of $\mathrm{PM}_{2.5}$ to the human body. As a new type of biological filter medium, microorganisms have been used in indoor and automobile air purifiers [9]. Lactobacillus has been evaluated for its ability to remove various toxins, but very little was found in the literature on the studies of Lactobacillus as the main biological filter medium [23]. Our present study is designed to use lactic acid bacteria strains to remove the toxicity from $\mathrm{PM}_{2.5}$ in terms of their $\mathrm{B}(\mathrm{a}) \mathrm{P}$ binding ability.

Our previous studies confirmed that Lactobacillus plantarum 121, Leuconostoc mesenteroides DM1-2, Lactobacillus acidophilus NCFM, Lactobacillus paralimentarius 412, and Lactobacillus pentosus ML32 had good adsorption effects on $\mathrm{B}(\mathrm{a}) \mathrm{P}$ [21]. In our present study, it is interesting to note that five tested bacteria exhibited some ability to bind $\mathrm{B}(\mathrm{a}) \mathrm{P}$, and at least $36.70 \% \mathrm{~B}(\mathrm{a}) \mathrm{P}$ was absorbed by these lactic acid bacteria strains. Additionally, their B(a)P absorbing capacity is observed to be species-specific. Among the tested strains, L. acidophilus NCFM has the best ability to bind $\mathrm{B}(\mathrm{a}) \mathrm{P}(60.0 \%)$. As potential decontaminating agents of aflatoxin B1 (AFB1) and B(a)P, the removal ability of lactic acid bacteria to the mutagenic compounds differs 


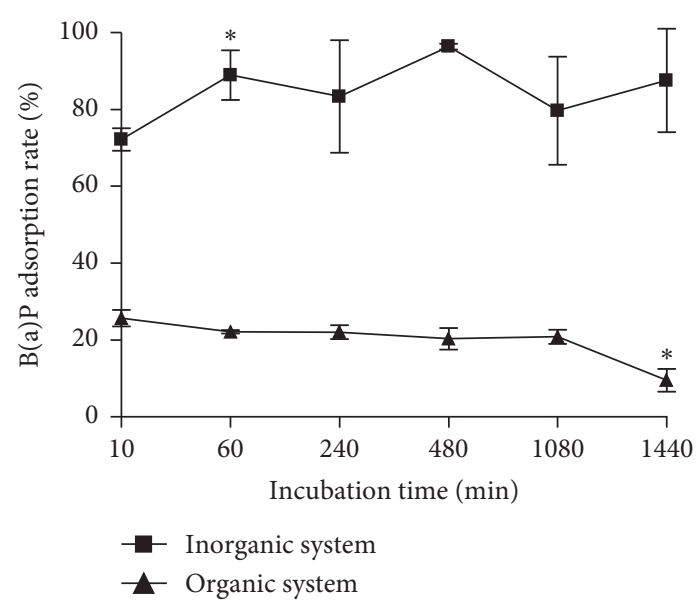

(a)

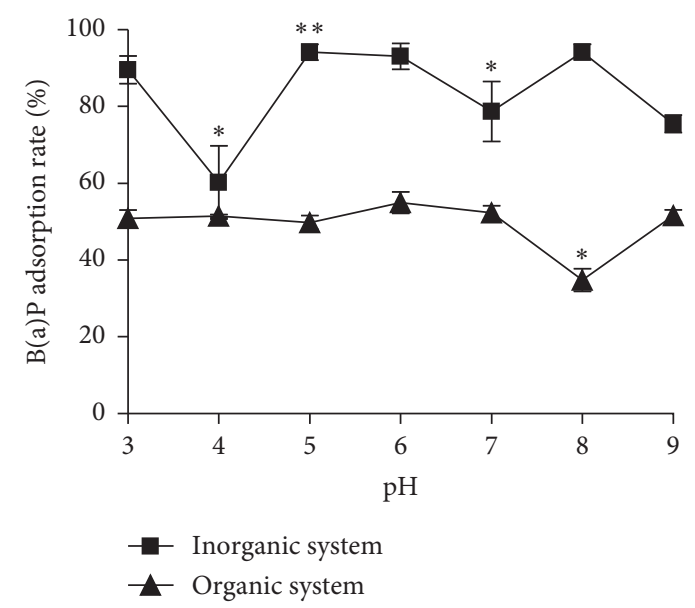

(c)

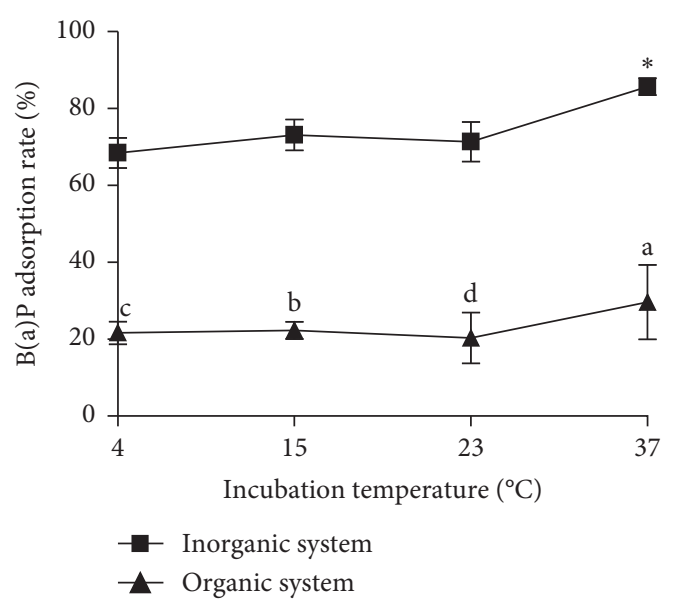

(b)

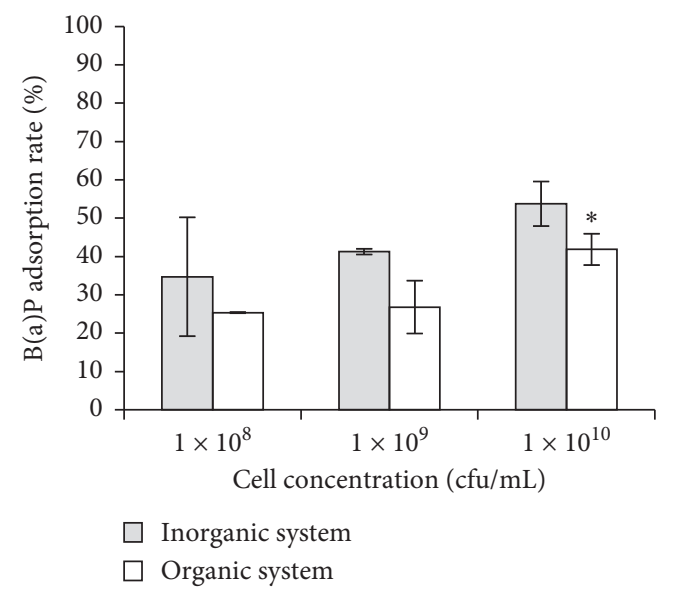

(d)

Figure 2: Factors affecting the binding ability of L. acidophilus NCFM to B(a)P existing in two simulated $\mathrm{PM}_{2.5}$, i.e., inorganic system and organic system: (a) effect of incubation time on B(a)P binding by strain NCFM, (b) effect of temperatures on B(a)P binding by strain NCFM, (c) effect of $\mathrm{pH}$ on $\mathrm{B}(\mathrm{a}) \mathrm{P}$ binding by strain NCFM, and (d) effect of cell concentrations of strain NCFM on its $\mathrm{B}(\mathrm{a}) \mathrm{P}$ binding. Note: ${ }^{*} P<0.05$ and ${ }^{* *} P<0.01$ compared with the control group.

from strain to strain in various medium surroundings. Our results are in accordance with what have been reported so far $[14,24]$.

Regarding the composition of $\mathrm{PM}_{2.5}$, it includes sulfate, nitrate, ammonium salts, carbonaceous particles, metal particles, minerals, and the polycyclic aromatic hydrocarbon (PAH) family. The current studies have implicated that $\mathrm{B}(\mathrm{a}) \mathrm{P}$ is one of the causative agents in colon cancer [25]. Epidemiological studies provide evidence for dietary intake of PAHs which is associated with colorectal cancer risk [26]. On the question of the mechanism of colon tumorigenesis as a result of $\mathrm{B}(\mathrm{a}) \mathrm{P}$ ingestion, $\mathrm{B}(\mathrm{a}) \mathrm{P}$ could lead to a differential induction of cytochrome $\mathrm{P} 450$ both in the liver and colon, and its ability of malignant transformation of colon epithelial cells has also been documented [27, 28]. Lactobacillus mostly colonized rats' colon and ileum and has shown promise in preventing colon carcinomas in rats [29]. In addition to bind $\mathrm{B}(\mathrm{a}) \mathrm{P}$, Lactobacillus kefir strains were reported to interact with metal ions via their binding ability [30]. Similar studies showed that Lactobacilli strains had good ability to bind various chemicals in various simulated environments [16, 31]. Interestingly, these studies have confirmed that the $\mathrm{B}(\mathrm{a}) \mathrm{P}$ binding efficiency is species-specific and depends on Lactobacillus cell structures. Several reports have shown that the adsorption of mycotoxins to the cell wall of Lactobacillus was attributable to their surface properties and mainly to their hydrophobicity $[32,33]$. In addition, literatures have revealed that the adsorption of toxins by microorganisms mainly depends on the specific chemical composition of the cell wall such as the peptidoglycan, teichoic acids, and teichuronic acids of Gram-positive bacteria [34-36]. Therefore, it seems that adsorption of Lactobacillus is dependent on the hydrophobicity and cell wall structure. A note of caution is due to the limited binding site on the cell wall since binding efficiency changes with different environments. Most components in $\mathrm{PM}_{2.5}$ could be absorbed by Lactobacillus cells, but previous studies have not reported how the organic and inorganic systems which resemble $\mathrm{PM}_{2.5}$ affect Lactobacillus strains to bind with B(a)P. Dutton et al. directly simplified the most complex component environments into two types, i.e., 


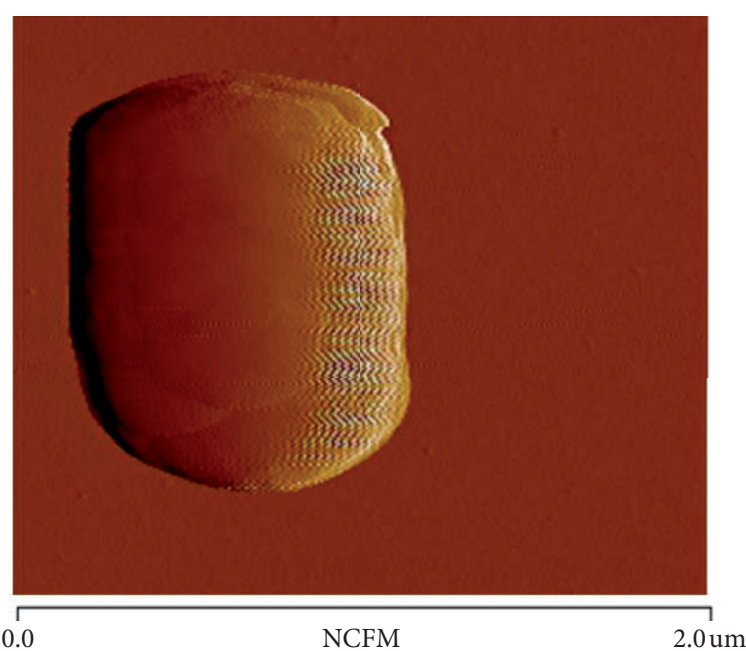

(a)

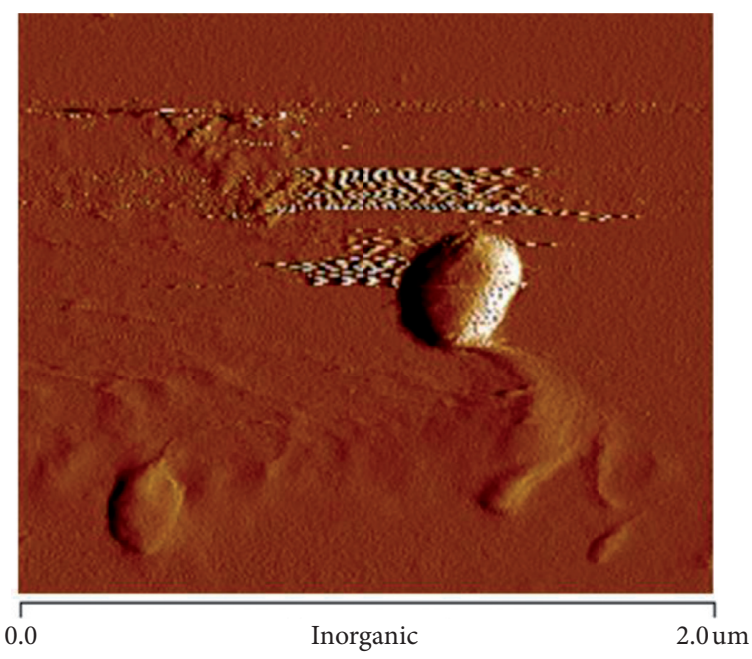

(c)

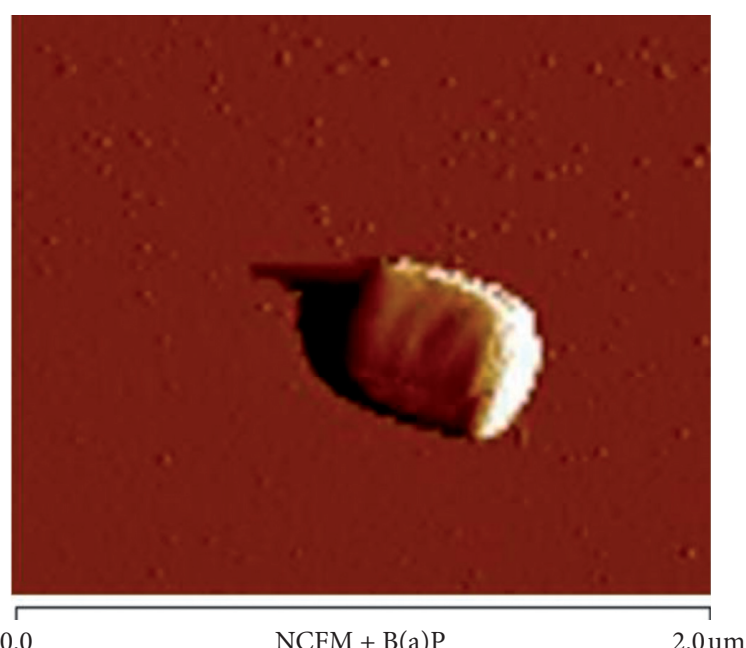

(b)

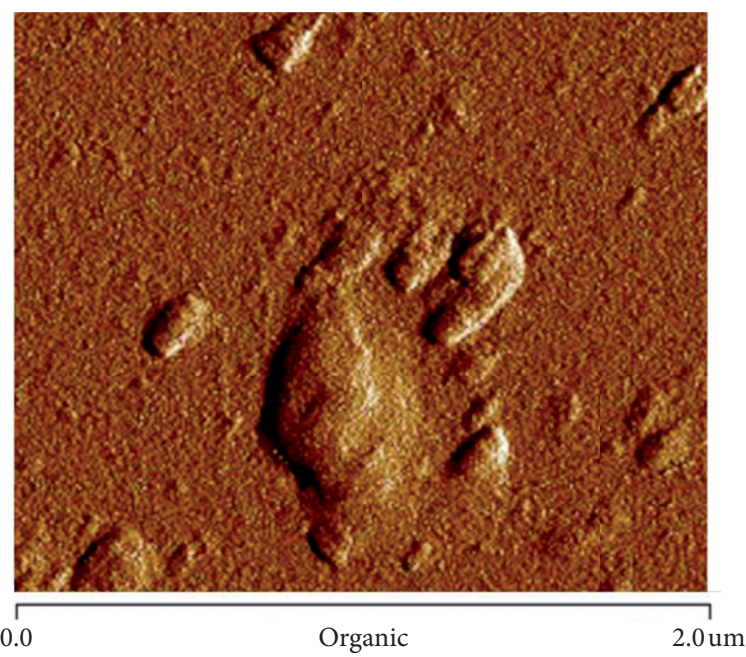

(d)

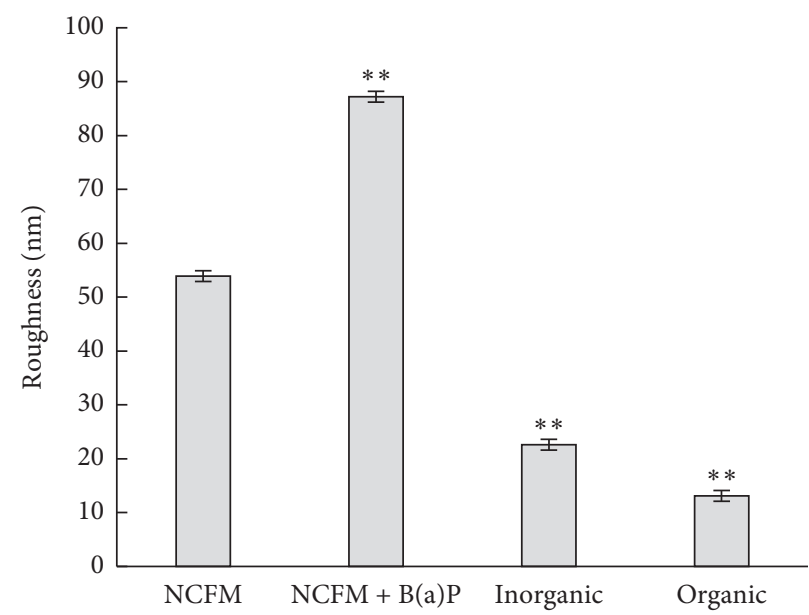

(e)

FIGURE 3: Factors affecting the binding ability of L. acidophilus NCFM to B(a)P existing in $\mathrm{PM}_{2.5}$, i.e., inorganic system and organic system: (a) AFM images of strain NCFM, (b) AFM images of B(a)P binding by strain NCFM, (c) AFM images of the inorganic system, (d) AFM images of the organic system, and (e) surface roughness analysis using AFM images (a, b, c, and d). Note: ${ }^{*} P<0.05$ and ${ }^{* *} P<0.01$ compared with strain NCFM. 
organic and inorganic systems [37]. The simplified systems easily allow us to evaluate the toxicity of $\mathrm{PM}_{2.5}$ supplemented with $\mathrm{B}(\mathrm{a}) \mathrm{P}$. In our case, we used the organic and inorganic systems which were supplemented with $\mathrm{B}(\mathrm{a}) \mathrm{P}$ in vitro to simulate $\mathrm{PM}_{2.5}$. Then, the ability of the tested L. acidophilus NCFM to bind $\mathrm{B}(\mathrm{a}) \mathrm{P}$ was evaluated in $\mathrm{PM}_{2.5}$. It was seen that the tested $L$. acidophilus NCFM bound $\mathrm{B}(\mathrm{a}) \mathrm{P}$, and its $\mathrm{B}(\mathrm{a}) \mathrm{P}$ binding percentages were high in the simulated organic and inorganic systems. Thus, it is presumed from our in vitro test that use of selected lactic acid bacterial strains as a biofilter agent should have potential in removing the toxicity of $\mathrm{PM}_{2.5}$.

Numerous studies state that the roles of lactic acid bacteria in absorbing various chemicals such as ochratoxin $\mathrm{A}$ and aflatoxins depend largely on parameters such as incubation time, cultivation temperature, $\mathrm{pH}$ values, and viable cell counts [31]. The stability of the aflatoxin B1bacteria complex appears to be species-specific [31]. This study confirms that the binding percentage of the mycotoxin by Lactobacillus is associated with incubation time [38]. Piotrowska found the ability of three lactic acid bacteria species in removing ochratoxin $\mathrm{A}$, and heating made higher toxin-binding ability [39]. Aflatoxin B1 bound by lactic acid bacteria was $\mathrm{pH}$-dependent, and a similar finding was also reported by Serrano et al. [40, 41]. Bacterial concentration is the other factor that strongly affects the removal of PAHs [17]. Studies showed that removal of aflatoxin M1 was significantly affected by microbial concentration [42]. Thus, the maximum adsorption of lactic acid bacteria cells to benzopyrene should be optimized. In our case, the optimized conditions are as follows: incubation temperature of $37^{\circ} \mathrm{C}$, incubation time of $8 \mathrm{hr}, \mathrm{pH}$ of 5 , and $1 \times 10^{10} \mathrm{cfu} / \mathrm{mL}$ for the inorganic system. In this case, $92.74 \%$ B(a)P is removed by L. acidophilus NCFM. For the organic system with $\mathrm{pH}$ of 6, L acidophilus NCFM binds $73.00 \% \mathrm{~B}(\mathrm{a}) \mathrm{P}$ only within $10 \mathrm{~min}$ when this strain is cultured at $37^{\circ} \mathrm{C}$ with a cell concentration of $1 \times 10^{10} \mathrm{cfu} / \mathrm{mL}$. In vivo, $\mathrm{pH}$ of the colon is stable at around 6.8 , and the imbalance of $\mathrm{pH}$ in tissues is directly linked to diseases such as cancer [43]. These results suggest that Lactobacillus acidophilus NCFMTM may potentially prevent colon cancer development, and Lactobacillus acidophilus NCFMTM significantly suppressed AOM-induced colon carcinogenesis in a dose-dependent manner [44]. This corresponds with our earlier observations, which showed that the optimized conditions were suitable for $\mathrm{B}(\mathrm{a}) \mathrm{P}$ binding in the colon.

The presence of $\mathrm{PM}_{2.5}$ caused the $\mathrm{B}(\mathrm{a}) \mathrm{P}$-binding cells to be changed in their morphology, as observed in our study (Figure 3). A similar report indicated that $\mathrm{PM}_{2.5}$ treatment destroyed the integrity of bacterial cells which shrank or suffered defects [15]. Importantly, the cell wall-prone status decreased because the main component of the cellular wall is composed of peptidoglycans [15]. This also accords with our earlier observations, which showed that more compounds existing in the complex $\mathrm{PM}_{2.5}$ were bound by NCFM strain cells compared to $\mathrm{B}(\mathrm{a}) \mathrm{P}$ environment only. Thus, analysis of AFM further proved that our selected NCFM strain was possible to be used as a precautionary agent for the reduction of PM2.5 pollutants due to its $\mathrm{B}(\mathrm{a}) \mathrm{P}$ binding ability.

\section{Conclusions}

Five tested lactic acid bacteria strains showed ability to bind $\mathrm{B}(\mathrm{a}) \mathrm{P}$ to some certain extent, but $L$. acidophilus NCFM exhibited the best capacity to bind B(a)P. At least $60 \% \mathrm{~B}(\mathrm{a}) \mathrm{P}$ was bound by this probiotic bacterium. This process of L. acidophilus NCFM to bind $\mathrm{B}(\mathrm{a}) \mathrm{P}$ was affected by incubation time, cultivation temperature, $\mathrm{pH}$, and cell concentration. The simplification of $\mathrm{PM}_{2.5}$ into inorganic and organic systems provided a model for us to evaluate the roles of lactic acid bacteria strains in reducing the damage of the polluted environments to human beings. There were significant differences in the binding percentage of L. acidophilus NCFM to B(a)P between the two simulated systems, but our in vitro data indicated that strain NCFM exhibited good possibility to remove $\mathrm{B}(\mathrm{a}) \mathrm{P}$ existing in simulated $\mathrm{PM}_{2.5}$. Currently, environmental pollution situation becomes more and more serious, and thus, using probiotic bacteria to relieve environmental hazards will be a new attempt.

\section{Data Availability}

The data used to support the findings of this study are included within the article.

\section{Conflicts of Interest}

The authors declare no conflicts of interest.

\section{Acknowledgments}

This study was partly funded by the National Natural Science Foundation of China (no. 31471710) and the Fundamental Research Funds for the Central Universities (no. 2015ZCQSW-05).

\section{References}

[1] M. Franklin, A. Zeka, and J. Schwartz, "Association between $\mathrm{PM}_{2.5}$ and all-cause and specific-cause mortality in 27 US communities," Journal of Exposure Science \& Environmental Epidemiology, vol. 17, no. 3, pp. 279-287, 2007.

[2] M. A. Kioumourtzoglou, J. D. Schwartz, M. G. Weisskopf et al., "Long-term $\mathrm{PM}_{2.5}$ exposure and neurological hospital admissions in the Northeastern United States," Environmental Health Perspectives, vol. 124, no. 1, pp. 23-29, 2016.

[3] World Health Organization International Agency for Research on Cancer, IARC: Outdoor Air Pollution a Leading Environmental Cause of Cancer Deaths, World Health Organization International Agency for Research on Cancer, Lyon, France, 2013, https://www.iarc.fr/en/media-centre/pr/ 2013/pdfs/pr221_E.pdf.

[4] K. F. Ho, S. C. Lee, C. K. Chan, J. C. Yu, J. C. Chow, and X. H. Yao, "Characterization of chemical species in $\mathrm{PM}_{2.5}$ and $\mathrm{PM}_{10}$ aerosols in Hong Kong," Atmospheric Environment, vol. 37, no. 1, pp. 31-39, 2003.

[5] K. D. Dhananjay, M. K. Deb, Y. Suzuki, and G. N. Kouvarakis, "Water-soluble ionic composition of $\mathrm{PM}_{2.5-10}$ and $\mathrm{PM}_{2.5}$ aerosols in the lower troposphere of an industrial city Raipur, the eastern central India," Air Quality, Atmosphere and Health, vol. 6, pp. 95-110, 2013. 
[6] J. Zhang, L. Chang, H. Jin et al., "Benzopyrene promotes lung cancer A549 cell migration and invasion through up-regulating cytokine IL8 and chemokines CCL2 and CCL3 expression," Experimental Biology and Medicine, vol. 241, no. 14, pp. 1516-1523, 2016.

[7] A. U. Lewandowska, M. Staniszewska, A. Witkowska, M. Machuta, and L. Falkowska, "Benzo(a)pyrene parallel measurements in $\mathrm{PM}_{1}$ and $\mathrm{PM}_{2.5}$ in the coastal zone of the Gulf of Gdansk (Baltic Sea) in the heating and non-heating seasons," Environmental Science and Pollution Research, vol. 25, pp. 19458-19469, 2018.

[8] M. Iriti, P. Piscitelli, E. Missoni, and A. Miani, "Air pollution and health: the need for a medical reading of environmental monitoring data," International Journal of Environmental Research and Public Health, vol. 17, no. 7, Article ID 2174, 2020.

[9] L. Jing, M. Li, F. Shen, Z. Zou, M. Yao, and C. Wu, "Characterization of biological aerosol exposure risks from automobile air conditioning system," American Chemical Society, vol. 47, pp. 10660-10666, 2013.

[10] E. M. Tuomola and S. J. Salminen, "Adhesion of some probiotic and dairy Lactobacillus strains to Caco-2 cell cultures," International Journal of Food Microbiology, vol. 41, pp. 45-51, 1998.

[11] B. Wang, J. Li, Q. Li, H. Zhang, and N. Li, "Isolation of adhesive strains and evaluation of the colonization and immune response by Lactobacillus plantarum L2 in the rat gastrointestinal tract," International Journal of Food Microbiology, vol. 132, no. 1, pp. 59-66, 2009.

[12] S. P. Pithva, J. M. Dave, and B. R. M. Vyas, "Binding of acridine orange by probiotic Lactobacillus rhamnosus strains of human origin," Annals of Microbiology, vol. 65, pp. 112123, 2015.

[13] V. I. Chalova, J. M. Lingbeck, Y. M. Kwon, and S. C. Ricke, "Extracellular antimutagenic activities of selected probiotic Bifidobacterium and Lactobacillus spp. as a function of growth phase," Journal of Environmental Science and Health, Part B, vol. 43, no. 2, pp. 193-198, 2008.

[14] Y. Qi, J. Zhang, X. Pan, J. Pei, and B. Zhang, "Binding of benzo(a)pyrene by Lactobacilli strains," Acta Microbiologica Sinica, vol. 51, pp. 956-964, 2011.

[15] H. Zhao, F. Zhou, Y. Qi et al., "Screening of Lactobacillus strains for their ability to bind benzo(a)pyrene and the mechanism of the process," Food and Chemical Toxicology, vol. 59, no. 59, pp. 67-71, 2013.

[16] X. He, L. Zhao, B. Zhang, and H. Zhao, "Removal of benzo(a) pyrene by Lactobacillus strains under simulated starch conditions," Acta Microbiologica Sinica, vol. 56, pp. 814-823, 2016.

[17] M. Yousefi, N. Shariatifar, M. Tajabadi Ebrahimi et al., "In vitroremoval of polycyclic aromatic hydrocarbons by lactic acid bacteria," Journal of Applied Microbiology, vol. 126, no. 3, pp. 954-964, 2019.

[18] W. R. Qin and H. B. Tang, "Fast determination of B(a)p in water by HPLC-RF," The Administration and Technique of Environmental Monitoring, vol. 4, pp. 31-32, 2000.

[19] X. Niu and S. Chen, "Determination of polycyclic aromatic hydrocarbons in $\mathrm{PM}_{2.5}$ by high performance liquid chromatography," Journal of Environmental Hygiene, vol. 5, pp. 65-70, 2015.

[20] H. Tanaka, H. Aoyagi, and T. Jitsufuchi, "Turbidimetric measurement of cell biomass of plant cell suspensions," Journal of Fermentation and Bioengineering, vol. 73, no. 2, pp. 130-134, 1992.
[21] S. Y. Zhang, D. Shao, H. Liu et al., "Metabolomics analysis reveals that benzo[a]pyrene, a component of $\mathrm{PM}_{2.5}$, promotes pulmonary injury by modifying lipid metabolism in a phospholipase A2-dependent manner in vivo and in vitro," Redox Biology, vol. 13, pp. 459-469, 2017.

[22] C. Siyi, Y. Wang, B. Zhao, S. Wang, X. Chang, and J. Hao, "The impact of the "air pollution prevention and control action plan" on $\mathrm{PM}_{2.5}$ concentrations in Jing-Jin-Ji region during 2012-2020," Science of the Total Environment, vol. 580, pp. 197-209, 2017.

[23] I. F. Cheng and H. C. Changa, "An integrated dielectrophoretic chip for continuous bioparticle filtering, focusing, sorting, trapping, and detecting," Biomicrofluidics, vol. 1, pp. 1-15, Article ID 021503, 2007.

[24] C. A. Haskard, H. S. El-Nezami, P. E. Kankaanp, S. Salminen, and J. T. Ahokas, "Surface binding of aflatoxin B1 by lactic acid bacteria," Applied and Environmental Microbiology, vol. 67, no. 7, pp. 3086-3091, 2001.

[25] Z. Fu, M. J. Shrubsole, W. E. Smalley et al., "Lifestyle factors and their combined impact on the risk of colorectal polyps," American Journal of Epidemiology, vol. 176, no. 9, pp. 766776, 2012.

[26] R. Sinha, K. Martin, M. J. Gunter, S. Paul, and N. Rothman, "Dietary benzo[a]pyrene intake and risk of colorectal adenoma," Cancer Epidemiology Biomarkers \& Prevention, vol. 14, no. 8, pp. 2030-2034, 2005.

[27] L. D. Deacqunita, J. N. Myers, L. D. Banks et al., "Influence of dietary fat type on benzo(a)pyrene $[\mathrm{B}(\mathrm{a}) \mathrm{P}]$ biotransformation in a $\mathrm{B}(\mathrm{a}) \mathrm{P}$-induced mouse model of colon cancer," The Journal of Nutritional Biochemistry, vol. 24, no. 12, pp. 2051-2063, 2013.

[28] A. Hakura, Y. Seki, J. Sonoda et al., "Rapid induction of colonic adenocarcinoma in mice exposed to benzo[a]pyrene and dextran sulfate sodium," Food and Chemical Toxicology, vol. 49, no. 11, pp. 2997-3001, 2011.

[29] L. O. Sarem-Damerdji, F. S. L. Marchal, and J. P. Nicolas, "In vitro colonization ability of human colon mucosa by exogenous Lactobacillus strains," FEMS Microbiology Letters, vol. 131, no. 2, pp. 133-137, 1995.

[30] E. Gerbino, P. Mobili, E. Tymczyszyn, R. Fausto, and A. Gómez-Zavaglia, "FTIR spectroscopy structural analysis of the interaction between Lactobacillus kefir S-layers and metal ions," Journal of Molecular Structure, vol. 987, no. 1-3, pp. 186-192, 2011.

[31] A. Nowak and Z. Libudzisz, "Ability of probiotic Lactobacillus casei DN 114001 to bind or/and metabolise heterocyclic aromatic amines in vitro," European Journal of Nutrition, vol. 48, no. 7, pp. 419-427, 2009.

[32] C. Guo, Y. Yuan, T. Yue, S. Hatab, and Z. Wang, "Binding mechanism of patulin to heat-treated yeast cell," Letters in Applied Microbiology, vol. 55, no. 6, pp. 453-459, 2012.

[33] L. Wang, T. Yue, Y. Yuan, Z. Wang, M. Ye, and R. Cai, “A new insight into the adsorption mechanism of patulin by the heatinactive lactic acid bacteria cells," Food Control, vol. 50, pp. 104-110, 2015.

[34] A. Zinedine, J. M. Soriano, J. C. Moltó, and J. Mañes, "Review on the toxicity, occurrence, metabolism, detoxification, regulations and intake of zearalenone: an oestrogenic mycotoxin," Food and Chemical Toxicology: An International Journal Published for the British Industrial Biological Research Association, vol. 45, no. 1, pp. 1-18, 2007.

[35] A. Zoghi, K. K. Darani, and S. Sohrabvandi, "Surface binding of toxins and heavy metals by probiotics," Mini Reviews in Medicinal Chemistry, vol. 14, no. 1, pp. 84-98, 2014. 
[36] A. Sangsila, V. Faucet-Marquis, A. Pfohl-Leszkowicz, and I. Pariyaporn, "Detoxification of zearalenone by Lactobacillus pentosus strains," Food Control, vol. 62, pp. 187-192, 2016.

[37] S. J. Dutton, S. Vedal, R. Piedrahita, J. B. Milford, S. L. Miller, and M. P. Hannigan, "Source apportionment using positive matrix factorization on daily measurements of inorganic and organic speciated $\mathrm{PM}_{2.5}$," Atmospheric Environment, vol. 44, no. 23, pp. 2731-2741, 2010.

[38] A. Chlebicz and K. Slizewska, "In vitro detoxification of aflatoxin B1, deoxynivalenol, fumonisins, T-2 toxin and zearalenone by probiotic bacteria from genus Lactobacillus and Saccharomyces cerevisiae yeast," Probiotics and Antimicrobial Proteins, vol. 12, pp. 289-301, 2020.

[39] M. Piotrowska, "The adsorption of ochratoxin A by Lactobacillus species," Toxins, vol. 6, no. 9, pp. 2826-2839, 2014.

[40] S. Fuchs, G. Sontag, R. Stidl, V. Ehrlich, M. Kundi, and S. Knasmüller, "Detoxification of patulin and ochratoxin A, two abundant mycotoxins, by lactic acid bacteria," Food and Chemical Toxicology, vol. 46, no. 4, pp. 1398-1407, 2008.

[41] J. C. Serrano-Niño, A. Cavazos-Garduño, A. F. GonzálezCórdova, B. Vallejo-Cordoba, A. Hernández-Mendoza, and H. S. García, "In vitro study of the potential protective role of Lactobacillus strains by acrylamide binding," Journal of Food Safety, vol. 34, no. 1, pp. 62-68, 2014.

[42] A. Ismail, R. E. Levin, M. Riaz, S. Akhtar, Y. Y. Gong, and C. A. F. de Oliveira, "Effect of different microbial concentrations on binding of aflatoxin M1 and stability testing," Food Control, vol. 73, pp. 492-496, 2017.

[43] P. A. Schornack and R. J. Gillies, "Contributions of cell metabolism and $\mathrm{H}^{+}$diffusion to the acidic $\mathrm{pH}$ of tumors," Neoplasia, vol. 5, no. 2, pp. 135-145, 2003.

[44] C. V. Rao, M. E. Sanders, C. Indranie, B. Simi, and B. S. Reddy, "Prevention of colonic preneoplastic lesions by the probiotic Lactobacillus acidophilus NCFMTM in F344 rats," International Journal of Oncology, vol. 14, no. 5, pp. 939-944, 1999. 